Rocznik Gdański, t. LXXIX

2019 PL ISSN 0080-3456

WALDEMAR BORZESTOWSKI ${ }^{1}$

\title{
NIEMCY WŚRÓD PRACOWNIKÓW MIEJSKICH ZAKŁADÓW KOMUNIKACYJNYCH MIASTA GDAŃSK I MIĘDZYKOMUNALNYCH ZAKŁADÓW KOMUNIKACYJNYCH GDAŃSK GDYNIA W LATACH 1945-1949. WNIOSKI Z ANALIZY AKT OSOBOWYCH
}

\author{
Wprowadzenie - kontekst
}

Kwiecień. Grzmią jeszcze ustawione na ulicach Gdyni działa. Bo na Oksywiu są Niemcy. Od huku tynk odpada z sufitu, lecą przedwcześnie wstawione szyby. Błysk wystrzałów rozświetla mieszkania ostrym światłem. Kogoś rozerwała mina. Nad brzegiem morza bzykają kule. Kamienna Góra, najeżona lufami dział, strzeże Gdyni i grozi broniącym się na Helu Niemcom ${ }^{2}$. A na wodach zatoki, jak złowrogie wspomnienie, tkwi jeszcze resztka niemieckiej floty, skupionej koło Helu.

Nie ma światła, nie ma gazu, nie ma wody i niewiele jest do jedzenia. W stołówce PCK na wprost Zarządu Miejskiego tłoczno. Tylko tam każdy może dostać gorący posiłek.

Otwiera się pierwsza restauracja przy ulicy 10 lutego. Za 60 zł zupa i gulasz. Kawiarnia przy ulicy Starowiejskiej wydaje zupy dla najuboższych z Opieki Społecznej. To wszystko. Ale wśród warkotów samolotów lecących na Hel i odgłosów walk toczących się na półwyspie przebija wyraźnie stukanie młotków w gdyńskich domach. Puste oczodoły okien zamykają łaty z tektury i dykty, wyrwane drzwi w rozgrabionych sklepach zastępują deski. Brygady Niemek uprzątają zasłane papierami i śmieciem ulice. Maj przynosi kapitulację Niemiec. Niemców prawie nie ma. Natomiast wiele jest ludności II i III grupy. 2000 podań o rehabilitację czeka na rozpatrzenie ${ }^{3}$.

\section{Bilans otwarcia}

Miasto Gdańsk w ostatnich miesiącach wojny uległo wyludnieniu. Z danych z 31 lipca 1945 roku wynika, że w mieście przebywało 122,8 tys. mieszkańców ${ }^{4}$ z czego

1 Uniwersytet Gdański, e-mail: w.borzestowski@wp.pl.

Jednostki niemieckie na Helu, od 40 do 60 tys. żołnierzy, skapitulowały 9 maja 1945 r.

3 Gdynia u progu 1946 roku. Wywiad z prezydentem miasta Gdyni H. Zakrzewskim (fragment), „Dziennik Bałtycki” nr 2, 03.01.1946 r.

4 Przed wojną, w 1939 r. - około 250 tys. 
107,2 tys. stanowili Niemcy5. Weryfikacji poddawano osoby posiadające obywatelstwo Wolnego Miasta Gdańska lub Trzeciej Rzeszy, które po wojnie deklarowały przynależność do narodu polskiego. Zweryfikowani pozytywnie mogli pozostać na miejscu. Niemców należało docelowo, w myśl ustaleń międzynarodowych, wysiedlić poza granice państwa. Polacy z zaanektowanego przez Rzeszę Pomorza, których nazwiska znalazły się na volkslistach ${ }^{6}$, składali podania o rehabilitację, stawali przed komisjami, by przekonać, że zostali przymuszeni do wpisu i podczas okupacji nie działali na szkodę narodu polskiego 7 .

Przed organami administracji składali oni deklarację wierności, za ich tożsamość ręczyli świadkowie. Nie wszyscy przechodzili tę próbę zwycięsko - w 1945 roku z grupy ponad 10 tys. osób, które poddały się tej procedurze, odrzucono 1090 wniosków. W następnym roku - 506, w kolejnym - 203 i w 1948 roku - już tylko sześć. W tym czasie łącznie na terenie Gdańska zweryfikowano 13265 osób, zrehabilitowano $2533^{8}$.

Nowa polska administracja czuwała nad zinwentaryzowaniem i zabezpieczeniem istniejącej infrastruktury, wszelkich dóbr, które uznawano za użyteczne. Jej zadaniem było również stworzenie warunków do życia dla mieszkających tu ludzi, pozyskanie bazy mieszkaniowej i miejsc pracy dla tych, którzy mieli tu niebawem przybyć. $\mathrm{Z}$ danych statystycznych dotyczących 1945 roku wyłania się ponury obraz zniszczonego miasta. Na 556 zakładów produkcyjnych, zewidencjonowanych w całym województwie, jedynie 150 mogło przystąpić do jakiejkolwiek działalności, niemal połowa budynków była całkowicie zrujnowana ${ }^{9}$. Niezwykle istotnym etapem przywracania normalności w funkcjonowaniu trzech nadmorskich miast była odbudowa połączeń komunikacyjnych. Ich uruchomienie w możliwie najkrótszym czasie i w kluczowych kierunkach stanowiło prawdziwe wyzwanie. Zarząd Miejski powołał w kwietniu 1945 roku Miejskie Zakłady Komunikacyjne miasta Gdańska (dalej: $\mathrm{MZK})^{10}$, które przekształcono dość szybko, bo już po roku, w duże, łączące trzy nad-

5 M. Stryczyński, Gdańsk w latach 1945-1948, Odbudowa organizmu miejskiego, Wrocław 1981, s. 154. Omówienie sytuacji Gdańska w 1945 r. w trakcie działań wojennych oraz bezpośrednio po jego zdobyciu zob. T. Glinecki, Atak na Gdańsk od strony Żuław w świetle dziennika działań bojowych 2. Armii Uderzeniowej za marzec 1945 roku [w:] Żuławy w 1945 roku. Niedomknięte księgi, red. T. Glinecki, M. Owsiński, Sztutowo 2018, s. 29-47; G. Baziur, Armia Czerwona na Pomorzu Gdańskim 1945-1947, Warszawa 2003; Pótwysep Helski. Historia orężem pisana, red. A. Drzewiecki, M. Kardas, Toruń 2009; R. Kieser, Zatoka Gdańska 1945. Dokumentacja dramatu, Gdańsk 2002.

6 Niemiecka Lista Narodowościowa.

7 Szerzej zob.: S. Bykowska, Rehabilitacja i weryfikacja narodowościowa ludności polskiej w województwie gdańskim po II wojnie światowej, Gdańsk 2012.

8 Przeglad statystyczny miasta Gdańska 1945-1950, z uzupetnieniami za rok 1951, s. 15.

9 K. Podoski, Województwo gdańskie w latach 1945-1959, Gdańsk 1958, s. 5-6.

10 S. Zomkowski, Tramwajem przez Gdańsk, Gdańsk 2015, s. 152. Z inicjatywy Zarządu Miejskiego Gdańska. Komunikacja miejska w aglomeracji gdańskiej. Rys historyczny. Stan obecny. Prognoza rozwoju, Gdańsk 1976, s. 13. 
morskie miasta przedsiębiorstwo Międzykomunalne Zakłady Komunikacyjne Gdańsk Gdynia (dalej: MZK GG) ${ }^{11}$. Firma miała liczne oddziały, do kluczowych należy zaliczyć: tramwajowy, autobusowy z podziałem na Gdańsk i Gdynię, trolejbusowy oraz sieć trakcji wodnej „Żegluga Gdańska” ${ }^{2}$.Z 229 wagonów tramwajowych należących do Verkehrsbetriebe Danzig Gotenhafen AG (dalej: VDG) ${ }^{13}$ żaden nie nadawał się do bezpośredniego uruchomienia, a 30 od razu przeznaczono do kasacji. Zniszczeniu uległo torowisko, ale przede wszystkim sieć trakcyjna ${ }^{14}$. W październiku 1945 roku firma MZK dysponowała zaledwie 12 silnikowymi wozami tramwajowymi i czterema doczepnymi oraz trzema autobusami kursującymi regularnie na trasie Gdańsk-Gdynia ${ }^{15}$. Intensywnie jednak pracowano nad oddaniem kolejnych. 31 października 1946 roku MZK GG wykazywało w sprawozdaniach, że posiada już 48 tramwajów i 27 autobusów ${ }^{16}$.

Starannie prowadzona ewidencja pracownicza MZK, a następnie MZK GG, to zespół kilku tysięcy teczek, zawierających liczne dokumenty ilustrujące przebieg pracy osób zatrudnionych w tym przedsiębiorstwie. Są one dość zróżnicowane, zazwyczaj zawierają kartę osobową, życiorys, podanie, rozmaite zaświadczenia, arkusze rozliczeń, raporty, bilety własne i rodzinne, zwolnienia lekarskie, książeczki mundurowe. Tak obszerna baza informacji pozwala stworzyć klarowny obraz załogi dużego i kluczowego dla funkcjonowania trzech miast zakładu pracy w ważnym momencie historycznym, przeciętnego wieku zatrudnionych, wykształcenia, pochodzenia (w sensie geograficznym i nie tylko), wojennych losów, stanu cywilnego, wyznawanej religii, stażu pracy, sposobu jej rozwiązania, dzietności, przynależności partyjnej etc. Mozaika tak wielu danych daje możność przeprowadzenia dokładnych analiz, które będą stanowić ważny element refleksji nad dziejami Gdańska i gdańszczan po 1945 roku.

Większość z przyjętych w latach 1945-1949 do MZK GG pracowników to ludzie młodzi ${ }^{17}$, w ponad $40 \%$ - stanu wolnego ${ }^{18}$. Byli słabo wykształceni ${ }^{19} \mathrm{i}$ na ogół marnie

11 MZK Gdańsk-Gdynia - pod tą nazwą przedsiębiorstwo funkcjonowało od 1 kwietnia 1946 r., S. Zomkowski, Tramwajem przez Gdańsk, s. 159. Firma swoim działaniem obejmowała również Sopot.

1230 października 1946 r. posiadała siedem jednostek. Prezydium Wojewódzkiej Rady Narodowej. Wydział Statystyki w Gdańsku, Rocznik statystyczny 1946, s. 73.

13 Przedsiębiorstwo transportowe Verkehrsbetriebe Danzig Gotenhafen AG, stworzone w 1942 r., obejmowało swoim działaniem całą aglomerację Gdańsk-Sopot-Gdynia. W jego strukturach znalazło się Danziger Elektrische Straßenbahn AG.

14 S. Zomkowski, Tramwajem przez Gdańsk, s. 153.

15 Archiwum Państwowe w Gdańsku (dalej: APG), 1165/1, s. 402, Okólniki i sprawozdania.

${ }_{16}$ Rocznik statystyczny miasta Gdańska 1946-1965, Gdańsk 1965, s. 145. Wedle innego źródła 46 wozów tramwajowych (w tym 21 silnikowych) oraz 43 tramwaje i 11 trolejbusów. Łączna długość funkcjonujących wówczas linii tramwajowych wynosiła niespełna $58,5 \mathrm{~km}$, autobusowych $-60 \mathrm{~km}$, trolejbusowych - 16 km. Prezydium Wojewódzkiej Rady Narodowej. Wydział Statystyki w Gdańsku, Rocznik statystyczny 1946, s. 73.

17 Od 20 do 35 lat - około 60\% ogółu. Tamże, s. 23.

$1842 \%$. Dane statystyczne wyprowadzone z analizy akt osobowych pracowników MZK i MZK GG, wynik badań prowadzonych przez autora tekstu (dalej cyt. Dane statystyczne wyprowadzone...).

19 Prawie 65\% pracowników posiadało pełne lub niepełne wykształcenie powszechne, a tylko ponad $2 \%$ - pełne lub niepełne wykształcenie wyższe. Tamże. 
przygotowani do wykonywanego zawodu, część z nich miała za sobą doświadczenie niewolniczej, przymusowej pracy w niemieckich fabrykach ${ }^{20}$ lub w gospodarstwach, byli wśród nich powracający do kraju jeńcy, więźniowie obozów koncentracyjnych, zdemobilizowani żołnierze ${ }^{21}$. Swoje podania o pracę zanosili do siedziby Dyrekcji MZK i MZK GG w Gdańsku-Wrzeszczu. Niekiedy przesyłali je pocztą. Stosowne skierowanie mógł wystawić referent pracy z Inspektoratu Osadnictwa Miejskiego, zgłaszając ten fakt Państwowemu Urzędowi Repatriacyjnemu. Pomorzanie, w tym byli obywatele Wolnego Miasta Gdańska, tworzyli liczną grupę pracowników ${ }^{22}$. Jednak samych gdańszczan było wśród nich stosunkowo niewielu ${ }^{23}$. Część z nich stanowili Niemcy. Można odnieść wrażenie, że nie wszyscy byli ewidencjonowani. Być może istniały ich osobne listy. Niektórzy są bowiem wzmiankowani w raportach, lecz nie ma ich kart w aktach osobowych. W sprawozdaniu z 13 sierpnia 1945 roku z działalności przedsiębiorstw użyteczności publicznej miasta Gdańska za okres od 15 kwietnia do 31 lipca 1945 roku podano, że w sekcji tramwajowej „aktualny stan zatrudnienia 625 osób, z czego 45 umysłowych i 325 fizycznych Polaków oraz 255 fizycznych Niemców" 24 oraz w sekcji autobusowej „aktualny stan zatrudnienia - 22 osoby z czego 2 umysłowe i 16 fizycznych Polaków oraz 4 fizycznych Niemców"25. Uzupełnieniem tej informacji jest wewnętrzna notatka $\mathrm{z}$ listopada 1945 roku: „Ze względu na zmniejszenie się stanu pracowników ze $180 \mathrm{w}$ dniu 05.09 br. na $159 \mathrm{w}$ dniu 05.11.1945 r. proszę o przyjęcie petenta do Wydziału Sieci i Torów"26. Wskazuje ona wyraźnie, jak nieliczna w tym czasie była załoga MZK. Choć od lata do jesieni miasto opuściło wielu Niemców ${ }^{27}$, należy sądzić, że również przez kilka kolejnych miesięcy stanowili oni wciąż ważną grupę wśród pracowników przedsiębiorstwa. Jako specjaliści, niekiedy byli pracownicy VDG, byli niezwykle cenni, wnieśli też istotny wkład w przywrócenie działania komunikacji w mieście. Można odnieść wrażenie, że ich obecność była szczególnie istotna w tak kluczowych wydziałach jak tramwajowy, autobusowy, trolejbusowy i w „Żegludze Gdańskiej”, gdzie każdy przeszkolony pracownik był na wagę złota ${ }^{28}$.

20 Ponad 10\%. Tamże.

${ }_{21}$ Ponad 10\%. Tamże.

22 Około 20\%. W grupie objętej kwerendą i obejmującej 2367 pracowników było ich 490. Prawie połowa $\mathrm{z}$ nich (46\%) zatrudniona była w wydziałach: ruchu, autobusowym i trolejbusowym. Tamże.

${ }^{23} 91$ osób, $18 \%$ w grupie Pomorzan, 3,8\% całości. Gdynian odpowiednio - 133 osoby, 27\% w grupie Pomorzan i 5,5\% całości. Tamże.

${ }_{24}$ APG, 1165/1, s. 407, Okólniki i sprawozdania.

25 Tamże, s. 408.

26 Archiwum Przedsiębiorstwa Gdańskie Autobusy i Tramwaje sp. z o. o., akta osobowe pracowników Miejskich Zakładów Komunikacyjnych i Międzykomunalnych Zakładów Komunikacyjnych Gdańsk Gdynia (dalej: AO-MZKGG), 1945/269.

27 Od czerwca do grudnia 1945 r. ponad 82 tys., M. Stryczyński, Gdańsk w latach 1945-1948..., tabela 37, s. 159.

${ }_{28}$ Wśród gdańszczan aż $20 \%$ znalazło pracę w Wydziale Ruchu, aż 68\% gdynian trafiło do wydziałów: ruchu, autobusowego i trolejbusowego. Dane statystyczne wyprowadzone... 


\section{Tajemniczy dyrektor, dozorca i inni}

Na podstawie odnalezionych dokumentów można jednoznacznie stwierdzić, że pierwszym dyrektorem MZK w trudnym czasie od kwietnia do lipca 1945 roku był George Vigoreck, nie zaś, jak podawała do niedawna znaczna część publikacji, Michał Bogusławski ${ }^{29}$. Vigoreck, występujący w polskich aktach pod zmienionym nazwiskiem jako Jerzy Wieczorek, to postać tajemnicza. Poświadczający jego działalność dokument pochodzi z początku 1950 roku, jego treść warto zacytować:

Biuro Personalne M.Z.K.G.G. uprzejmie komunikuje, że ob. Wieczorek Jerzy (Vigerga Georges), w naszych Zakładach figurujący jako Vigoreck George, był Dyrektorem Miejskich Zakładów Komunikacyjnych w Gdańsku w czasie kwiecień-lipiec 1945. Dokładnych danych nie możemy podać na skutek braku akt, gdyż w powyższym okresie czasu MZK Gdańsk należały administracyjnie do Inspektoratu Przedsiębiorstw Użyteczności Publicznej przy Zarządzie Miejskim w Gdańsku³ .

Wydane zaświadczenie stanowi odpowiedź na zapytanie wystosowane przez szefa Działu Personalnego Przedsiębiorstwa Państwowego Wyodrębnionego - Szczecińskich Zakładów Ceramiki Czerwonej, które chciało potwierdzić tożsamość nowo zatrudnionego pracownika, powołując się przy tym na informacje, które prawdopodobnie umieścił w swoim podaniu: „Dla orientacji podajemy, że ob. Wieczorek uruchomił tramwaje w Gdańsku w 1945 roku" ${ }^{31}$. Tych kilka zdań to w zasadzie jedyny ślad po człowieku, który wniósł, jak można sądzić, znaczący wkład w odbudowę komunikacji. Nie znajdziemy jego nazwiska w obszernym wykazie 42 przedstawicieli kadry kierowniczej MZK, MZK GG, przechowywanym w Archiwum Państwowym w Gdańsku ${ }^{32}$, wspomina o nim tylko zdawkowo w nieopublikowanej pracy, poświęconej powojennej historii komunikacji na Wybrzeżu Gdańskim ${ }^{33}$, dyrektor techniczny Wojewódzkiego Przedsiębiorstwa Komunikacyjnego Gdańsk-Gdynia ${ }^{34}$ Maciej Gwiazda $^{35}$. Napisał

29 Inżynier Michał Bogusławski, prawdopodobnie był dyrektorem MZK w Gdańsku już od 25 maja $1945 \mathrm{r}$.

30 AO-MZKGG, 1946/269.

31 Tamże.

32 APG, 1164/1333, Dokumenty Urzędu Wojewódzkiego w Gdańsku. Kwalifikacje pracowników MZK GG 1945-1947.

${ }_{33}$ M. Gwiazda, Komunikacja miejska Wybrzeża Gdańskiego. Odbudowa i rozwój w latach 1945-1980, Gdańsk 1992.

34 Wojewódzkie Przedsiębiorstwo Komunikacyjne Gdańsk-Gdynia (dalej: WPK GG), kolejna mutacja przedsiębiorstwa komunikacyjnego Wybrzeża Gdańskiego, powstało w 1951 r. i trwało w takiej postaci do $1974 \mathrm{r}$.

35 Maciej Gwiazda (1919-2008), działacz organizacji Szare Szeregi w Gdyni, podharcmistrz. Aresztowany przez gestapo w 1943 r., osadzony w obozie Stutthof, od 1946 r. w MZK GG, wieloletni dyrektor techniczny WPK GG. Absolwent Politechniki Gdańskiej, autor kilku opracowań dotyczących historii komunikacji. Od 2011 r. patron jednego z gdańskich tramwajów typu Pesa Swing 120NaG (nr 1045). Szerzej zob. A. Gąsiorowski, Szare Szeregi na Pomorzu 1939-1945, Toruń 1998. 
on, że Jerzy Wieczorek był prawdopodobnie z pochodzenia Francuzem i we wspomnianym czasie kierował jedynie pracami zabezpieczającymi ${ }^{36}$. Nie ma na to jednak żadnych dowodów.

O kolejnych mężczyznach, byłych obywatelach Freie Stadt Danzig zatrudnionych w MZK GG, wiemy również stosunkowo niewiele. Friedrich Schwerig ${ }^{37}$, ewangelik urodzony w 1873 roku, zamieszkały we Wrzeszczu, został zatrudniony jeszcze w czerwcu 1945 roku $^{38} \mathrm{w}$ Warsztatach Głównych ${ }^{39}$. Przy zatrudnieniu otrzymał stawkę wręcz skandalicznie niską - 3 zł na godzinę ${ }^{40} \mathrm{i}$ w lipcu 1946 roku zdecydował się wraz z żoną Luisą wyjechać do Niemiec. Maszynista Eryk Grunwald ${ }^{41}$, choć przedstawił w grudniu 1945 roku cenzurę rehabilitacyjną, wszelkie dokumenty opatrywał nagłówkami niemieckimi ${ }^{42}$. Był cennym nabytkiem dla MZK GG, miał duże doświadczenie w swoim zawodzie, wcześniej był zatrudniony „w dziale motorów w fabryce papierosów oraz w warsztatach Trojan-Gdańsk ${ }^{43}$ ". Równie doświadczonym pracownikiem był Leon Hering ${ }^{44}$, szachmistrz ${ }^{45}$ na wielu budowach, w latach 1940-1944 zatrudniony przy wznoszeniu nadmorskiej, ,od polskiej granicy - do Gdyni”, promenady ${ }^{46}$. Latem 1945 roku objął funkcję dozorcy w MZK. Urodzony w Gdańsku w 1902 roku Paweł Borhardt w swoim życiorysie wspominał: „od marca 1942-1943 pracowałem w warsztatach kolejowych w Gdańsku, a w roku 1943 przeszedłem do ruchu jako palacz pomocniczy" ${ }^{37}$. Został zweryfikowany pozytywnie w listopadzie 1946 roku i był zatrudniony w kilku działach aż do końca 1947 roku. Wtedy zwolnił się „na własne życzenie”. Jego dzieci nosiły imiona wyraźnie kojarzące się z kręgiem niemieckiej kultury: Walter, Günter i Werner, podobnie jak pozostająca pod jego opieką pasierbica - Abdelgunda.

Maksymilian Neumann ${ }^{48}$ zatrudniony był jako oponiarz w Wydziale Samochodowym w Gdańsku, a potem w Gdyni. Trafił do raportu z 2 maja 1946 roku: „przez okres jednego roku pracy w MZK nie stara się poznać języka polskiego, natomiast używa wyłącznie języka niemieckiego"49. Domagano się cofnięcia rehabilitacji i zwolnienia z pracy. Dyrekcja przychyliła się do tej sugestii, dokument bowiem opatrzono

36 M. Gwiazda, Komunikacja miejska Wybrzeża Gdańskiego..., s. 3.

37 AO-MZKGG, 1946/1043. Urodzony 16 grudnia 1873 r. w powiecie Osterode (obecnie Ostróda w województwie warmińsko-mazurskim).

3811 czerwca 1945 r. Tamże.

39 Zajezdnia we Wrzeszczu.

40 W tym czasie wynosiła od 4,20 do 8 zł za godzinę.

41 AO-MZKGG, 1946/266.

42 Abschrieft (zaświadczenie).

43 Warsztaty Kolejowe na Trojanie, inaczej na Przeróbce.

44 Rocznik 1876. AO-MZKGG, 1946/40.

45 Budowlaniec, specjalista od konstrukcji szachulcowych.

46 AO-MZKGG, 1946/40.

7 AO-MZKGG, 1946/78

48 AO-MZKGG, 1946/781.

49 Tamże. 
adnotacją: „Zwolnić od razu bez odszkodowania”"50, do czego jednak nie doszło. W tej sprawie zabrał głos naczelnik Wydziału Społeczno-Politycznego M. Wojewódzki, który z upoważnienia Prezydenta Miasta wystosował do MZK GG pismo wyjaśniające: „komunikujemy, że Maksymilian Neumann zweryfikowany został jako strona małżeństwa mieszanego - żona jego jest Polka. Nieznajomość języka polskiego nie może być powodem do cofnięcia Zaświadczenia Weryfikacyjnego. Zaznaczamy, że proces weryfikacyjny może być zrewidowany jedynie na wniosek czynników do tego powołanych przez Wojewódzką Komisję Weryfikacyjną"51. Pismo ostudziło zapędy dyrekcji, Neumann pozostał na swoim stanowisku aż do września 1947 roku. Zwolniono go w związku z reorganizacją przedsiębiorstwa, wpisując do odpowiedniej rubryki informację, że uczyniono to zgodnie z decyzją Wojewódzkiej Komisji Weryfikacyjnej ${ }^{52}$.

\section{Motorowi}

Kiedy 28 czerwca 1945 roku pierwszy tramwaj - „Jedynka”53 - wyruszył na ulice miasta, prowadził go Teodor Meus ${ }^{54}$. „Dziennik Bałtycki” niewiele miejsca poświęcił temu historycznemu wydarzeniu, stosowna informacja zawarta została w dwóch zdaniach, wśród innych dotyczących sieci wodociągowej, uporządkowania parków i ogrodów, a także wymiany szyldów ulicznych z niemieckich na polskie. Przybrała postać meldunku złożonego przez wicewojewodę gdańskiego: „Meldujemy jako dar dla kraju, w dniu »Święta Morza« Gdańsk uruchamia pierwszy tramwaj. Dokonano już próbnej jazdy na linii Wrzeszcz - Gdańsk, Dworzec Główny, oprócz tego uruchomiono 3 autobusy”55. Dopiero na początku lipca pojawiła się w prasie obszerniejsza relacja na ten temat, zaznaczono w niej nie bez dumy, że „Warszawa niedawno chlubiła się E.K.D. ${ }^{56}$ Gdańsk może poszczycić się tramwajem"57. Kiedy wspomnianego dnia pierwszy tramwaj wyruszył z zajezdni na ulice zniszczonego miasta w kierunku centrum Wrzeszcza ${ }^{58}$, większość spoglądających

50 Tamże.

51 Tamże.

52 Wojewódzka Komisja Weryfikacyjna działała na terenie województwa gdańskiego od marca 1946 do października 1947 r.

53 Nazwa trasy, pierwotnie od zajezdni we Wrzeszczu do skrzyżowania przy ulicy Jaśkowa Dolina. Tam znajdował się również budynek dyrekcji firmy (pod numerem 48).

${ }_{54}$ Teodor Meus (1912 r.), tramwajarz warszawski, w Gdańsku kierownik Wydziału Ruchu MZK GG.

${ }_{55}$ Nasz meldunek $w$ dniu „Święta morza” Konferencja prasowa u wicewojewody gdańskiego, „Dziennik Bałtycki” nr 35, 28.06.1945 r., s. 2.

56 Warszawska Elektryczna Kolej Dojazdowa. Funkcjonowała od 1927 r. jako pierwsza normalnotorowa kolej elektryczna w Polsce. 19 maja 1945 r. przywrócono regularny ruch z wykorzystaniem trakcji elektrycznej. Był to pierwszy po wojnie środek transportu publicznego w Warszawie.

57 (M. M.), Tramwajem gdańskim, „Dziennik Bałtycki” nr 40, 04.07.1945 r., s. 3.

58 W kierunku Jaśkowej Doliny. Tak podał w wywiadzie radiowym z 1963 r. Teodor Meus. Zbiory prywatne Stanisława Turzyńskiego. W niektórych publikacjach podano, że jechał do Opery 
na niego przechodniów stanowili dawni mieszkańcy miasta. Wspominał o tym w wywiadzie radiowym Teodor Meus „Prowadziłem wagon wolno, aby dać możność nielicznym wówczas Polakom, mieszkańcom Wrzeszcza i Gdańska, cieszenia się na równi z nami z tego historycznego momentu" ${ }^{\text {99 }}$.

Dopiero na przełomie października i listopada 1945 roku Polacy liczebnie zdominowali Niemców. Dawni niemieccy gdańszczanie powoli, lecz sukcesywnie opuszczali swoje miasto, w sierpniu 1946 roku w Gdańsku pozostawało ich jednak w dalszym ciągu 24 tys. ${ }^{60}$ To oni, niekiedy byli pracownicy VDG, stanowili pierwszą kadrę motorowych. Mirosława Walicka ${ }^{61}$, autorka Próby wspomnień. Gdańsk 1945-1946, napisała pod datą 29 czerwca 1945 roku:

Rusza pierwszy tramwaj. Trasa jednostronna od Jaśkowej Doliny do Bramy Oliwskiej ${ }^{62}$. Pierwszym konduktorem jest Franciszek Jefremczuk, przedwojenny tramwajarz warszawski. Przejazd tramwaju staje się wielkim świętem. Na trasie przejazdu jadącym zgotowano owacje. Na wozach brak napisów. Brak także tablic na przystankach. Wozy prowadzą na razie niemieccy motorniczowie. Szkolenie polskiej obsługi idzie pełną parą ${ }^{63}$.

Potwierdza to inna relacja, tym razem zebrana przez dziennikarza, który wybrał się tramwajem 4 lipca 1945 roku w kierunku Wrzeszcza. Przeprowadził on krótką rozmowę z urodzonym w Warszawie konduktorem. Ten stwierdził jednoznacznie: „Pracujemy na dwie zmiany, od 6 do 12 i od 12 do 18. Zarabiamy 50 zł dziennie, otrzymujemy obiad albo kolację w zależności od czasu pracy. Wozy prowadzą na razie niemcy (pisownia oryginalna). Kandydaci na motorowych praktykują i wkrótce będą mogli objąć służbę" ${ }^{64}$. Co znamienne, w artykułach i dokumentach w tym czasie narodowość Niemców z reguły pisano małą literą.

Jednym z prowadzących pierwsze tramwaje, a może także szkolącym nowych motorowych, mógł być Robert Rosin ${ }^{65}$. Urodzony w 1879 roku ewangelik, mieszkał z żoną we Wrzeszczu przy Jaśkowej Dolinie. Z jego piątki dzieci dwóch synów znalazło się w wojsku niemieckim, przy czym o jednym napisano, że zaginął. O losie córek tylko tyle wiadomo, że starsza zdecydowała się wyjechać do Niemiec. W swoim życiorysie Robert Rosin napisał: „Od roku 1920-1944 byłem zatrudniony jako motorowy-tramwajowy i do roku 1945 instruktor przy tramwajach w Gdańsku (w Danziger

Bałtyckiej. S. Zomkowski, Tramwajem przez Gdańsk, s. 155. Przed wojną w tym miejscu hala widowiskowa, gdzie urządzano również imprezy sportowe. Obecne skrzyżowanie ul. Hallera i al. Zwycięstwa.

59 Wywiad radiowy z 1965 r. Zbiory Stanisława Turzyńskiego.

60 M. Stryczyński, Gdańsk w latach 1945-1948... Liczba wynikła z porównania danych na s. 159 i 162.

${ }_{61}$ Mirosława Walicka (1917-2006), dziennikarka, autorka książek, należała do pierwszego zespołu redakcyjnego „Dziennika Bałtyckiego”.

${ }_{62}$ Według informacji prasowej tramwaj do przystanku przy Bramie Oliwskiej, gdzie bierze początek al. Zwycięstwa (wtedy Marszałka Rokossowskiego), dojeżdżał dopiero od 4 lipca 1945 r.

63 M. Walicka, Próba wspomnień, Gdańsk 1945-1946, Gdańsk 1968, s. 284.

64 (M.M.), Tramwajem gdańskim..., s. 3. Dane z akt osobowych podają, że było to $10 \mathrm{zł}$ za godzinę w 1945/1946 r., w maju 1948 r. - 15-17,54 zł za godzinę, Dane statystyczne wyprowadzone...

65 AO-MZKGG, 1946/727. 
Elektrische Straßenbahn)" ${ }^{\prime 6}$. Pracował w MZK od 14 maja 1945 roku w ważnym Wydziale Ruchu, potem został przeniesiony do Warsztatów Głównych, wreszcie jako dróżnik trafił do wydziału zajmującego się torami. W jego dokumentach znaleźć można tymczasowe, ważne na trzy miesiące od daty wystawienia, zaświadczenie weryfikacyjne z maja 1946 roku. Dotyczyło ono nie tylko Roberta Rosina, ale również jego żony Karoliny. W wystawionym przez prezydenta miasta Gdańska ${ }^{67}$ certyfikacie zapisano:

Na podstawie instrukcji Ministra Administracji Publicznej Departament Polityczny z dnia 20.06.1945 r. oraz zarząazenia Wojewody Gdańskiego w sprawie tymczasowych zaświadczeń dla obywateli Rzeszy niemieckiej (WMGdańsk) narodowości polskiej na nowo odzyskanych ziemiach polskich, zaświadcza się, że obywatel Robert Rosin złożył deklarację wierności Narodowi Polskiemu i Demokratycznemu Państwu Polskiemu $^{68}$ (pisownia oryginalna).

Robert Rosin zmarł 18 kwietnia 1946 roku, akt zgonu przyniosła do działu personalnego jego żona.

$$
\text { Żegluga }
$$

Pracownicy tego wydziału stanowili zaledwie 6\% wszystkich zatrudnionych w MZK GG ${ }^{69}$ i byli to niemal sami mężczyźni. Także i tu początkowo największą grupę pracowników stanowili Pomorzanie ${ }^{70}$. Część z nich posiadała wcześniej obywatelstwo Freie Stadt Danzig ${ }^{71}$. W pierwszym składzie pracowniczym znaleźć można Niemców. Jednym z nich był urodzony 18 maja 1913 roku maszynista żeglugowy Ryszard Pleger ${ }^{72}$, który napisał w swoim podaniu „Uprzejmie proszę o ofiarowanie mi pracy w charakterze maszynisty na linii wodno tramwajowej"73. W swoim życiorysie zaznaczył: „Jako maszynista pracowałem (od 1938 r.) do zakończenia działań wojennych w stoczni Nr. $4^{74}$ w Gdańsku"75. Dyrektor wydziału „Żegluga Gdańska” Janusz Minta $^{76}$ w piśmie do dyrekcji MZK

66 Tamże.

67 W tym czasie był nim Franciszek Kotus-Jankowski.

68 AO-MZKGG, 1946/727.

${ }_{69}$ Było ich ogółem 2251 - 332 umysłowych i 1919 fizycznych. Komunikacja miejska w aglomeracji gdańskiej, s. 16 i 18.

${ }^{70}$ Ponad 35\%. Liczba ta spadała sukcesywnie na przestrzeni trzech pierwszych lat, dochodząc do $9 \%$. Dane statystyczne wyprowadzone...

7113 osób jako miejsce urodzenia i zamieszkania podczas wojny podało Gdańsk.

72 AO-MZKGG, 1946/861.

73 Tamże.

74 Tak po wojnie, od czerwca 1945 r., określano dawną Stocznię Wojana (Wojan-Schiffswerft), w lutym 1943 r. przekształconą w Danziger Flussschiffswerft GmbH (Gdańską Stocznię Rzeczną Sp. z o.o.).

75 AO-MZKGG, 1946/861.

${ }^{76}$ Pierwszy dyrektor „Żeglugi Gdańskiej” MZK GG Trakcja wodna, przedwojenny gdyński armator. M. Gwiazda, Komunikacja miejska wybrzeża Gdańskiego..., s. 12. APG, 1164/1333, 
z 6 marca 1946 roku starał się uzasadnić decyzję o zatrudnieniu Niemca: „Uprzejmie proszę o przyjęcie niemca Pleger Richarda w charakterze maszynisty na okres tymczasowy. Nadmieniam, że po 3-tygodniowych staraniach nie znalazłem maszynistów Polaków. Wynagrodzenie proponuje zł 7,10 za godzinę" ${ }^{\text {"77 }}$. Ten sam dyrektor w kwietniu 1946 roku zdecydował się przyjąć kolejnego „miejscowego”, Huberta Schmidta ${ }^{78}$ : „Uprzejmie proszę o przyjęcie ob. niemca Schmidta Huberta w charakterze maszynisty na okres tymczasowy. Jako wynagrodzenie proponuję zł 8,50 na godzinę". Przełożony wyraził zgodę, lecz z zastrzeżeniem: „do czasu otrzymania polskiej siły”. Następnym fachmanem najętym do kadry żeglugowej był urodzony w 1904 roku i zamieszkały na Stogach ewangelik Herbert Andreys ${ }^{79}$. Jego podanie z 5 marca 1946 roku brzmi identycznie jak podanie Plegera: „Uprzejmie proszę o zaofiarowanie mi pracy na linii wodno tramwajowej w charakterze maszynisty". Przypuszczać można, że zbieżność nie jest przypadkowa. Być może mężczyźni korzystali z czyjejś pomocy przy pisaniu tekstu. Także tym razem dyrektor Minta zdecydował się w tej sprawie wystosować pismo do dyrekcji MZK GG ${ }^{80}$ : „Uprzejmie proszę o przyjęcie niemca Andreysa Herberta na okres tymczasowy w charakterze maszynisty do czasu znalezienia maszynistów Polaków"81.

Curriculum vitae nowego pracownika przytacza wiele faktów z jego życia:

Jestem wyznania ewangelickiego narodowości niemieckiej. Po ukończeniu szkoły powszechnej poszedłem pracować do zakładów budowy maszyn. Po 20 latach mej pracy w zakładach maszynowych w r. 1924 zacząłem pracować za palacza na lodołamaczu. Od roku 1939 do 1944 pracowałem na statkach w charakterze maszynisty. Kiedy zaczęły się zbliżać wojska sowieckie urzędnicy z firmy, w której pracowałem uciekli zabierając moje dyplomy z sobą lub zniszczyli.

Andreys pracował w „Żegludze Gdańskiej” od marca do końca sierpnia 1946 roku. Na jego karcie osobowej możemy odczytać dziwną adnotację: „powiadomiono telefonicznie o zwolnieniu na 31.08.1946 dnia 29.08.1946 o godzinie 9.30"82. 30 sierpnia 1946 roku dyrektor Minta wystąpił do dyrekcji MZK GG z wnioskiem:

Ze względu na urządzoną ewakuację zostaje zwolniony ze służby maszynista Żeglugi Gdańskiej niemiec Andres Hubert [pisownia oryginalna]. Z uwagi na to, że maszynista Andres spełniał swoje obowiązki z poczuciem obowiązkowości dla dobra przedsiębiorstwa, proponuję przyznać mu jednorazową premię w wysokości według uznania Dyrekcji MZKGG.

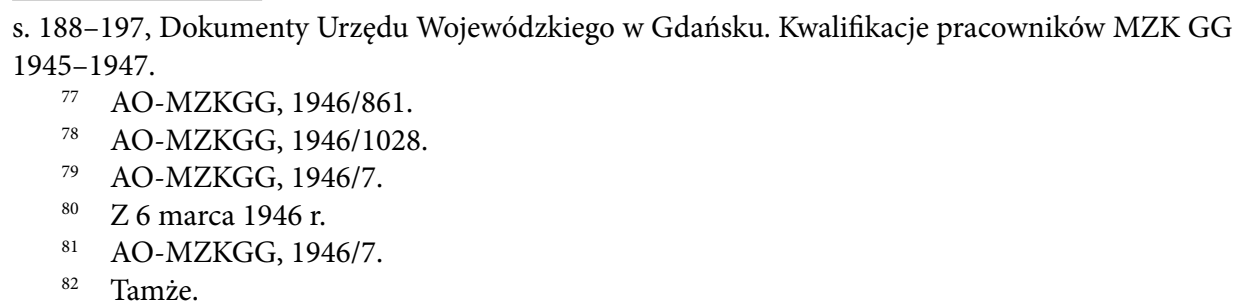


Dyrekcja 12 września 1946 roku odpowiedziała: „komunikujemy, że dec. Nacz. Dyrektora sprawa ta została załatwiona odmownie" ${ }^{83}$. Nie wiemy, kiedy Herbert Andreys, jego żona Else, a być może również syn Erik wyruszyli na zachód, jedno jest pewne - musiał być dobrym pracownikiem, skoro dyrektor kilkakrotnie wstawiał się za nim, ryzykując niechęć załogi, a nawet dyrekcji, która dochodzące do niej raporty czytała niezwykle skrupulatnie, podkreślając fragmenty uznane za godne wyjaśnienia.

\section{Afera cukrowa}

Dyrektor Minta starał się dobrze traktować wszystkich swoich pracowników, cenił tych, którzy mieli doświadczenie i znali się na swojej robocie. O kapitanów, maszynistów, bosmanów nie było łatwo. Również rotacja zatrudnionych w jego wydziale była duża, wielu traciło pracę $\mathrm{w}$ wyniku postępowania dyscyplinarnego ${ }^{84}$. Zwolnieni pisali niekiedy odwołania, domagali się zaległych poborów, tworzyli raporty, a właściwie donosy. Jeden z nich jest szczególnie obfity, stworzył go zwolniony z powodu zaniedbań i nagannego zachowania, zatrudniony na stanowisku biuralisty Alfred S. Konflikt między nim a przełożonym miał gwałtowny przebieg, dyrektor wyrzucał swojemu podwładnemu, że używa wobec niego gróźb i to w obecności osób trzecich. Ten zaś, odnosząc się do zarzutów zwierzchnika, wyraził w swoim raporcie przekonanie, że ukrył on prawdziwą przyczynę wypowiedzenia: „Powód mojego zwolnienia jest moim zdaniem zupełnie inny, a jest nim niechęć osobista ob. Minty powstała w ostatnich tygodniach mojej pracy w $\dot{Z} G^{85}$ na skutek coraz częstszego nalegania i przypominania, że czas zwolnić z pracy niemców Andresa i Schmidta, którzy przez obywatela Mintę byli zbyt po ojcowsku traktowani, obdarowani prezentami itp." ${ }^{86}$ Można odnieść wrażenie, że zwolniony wybrał sposób obrony poprzez atak nieprzypadkowo. Wiedział, że dyrekcja będzie musiała potraktować poważnie jego zarzuty. Sympatia do Niemców w latach 1945-1946 nie była dobrze postrzegana. Autor raportu skrupulatnie wyliczył przykłady niewłaściwego i podejrzanego z jego punktu widzenia traktowania Niemców przez dyrektora, nadmieniając przy okazji, że „powyższe zainteresowanie niemcami zauważyli też inni pracownicy jak obaj Wiśniewscy, ob. Furmanek, ob. Walczak i inni" ${ }^{87}$. Dalej czytamy:

Oto kilka faktów, które mnie dziwią i bolą jako Polaka [...] Około 29 kwietnia 1946 r. przyszło pismo z aprowizacji, że należy podać pracowników zatrudnionych przed 31 marca celem przydziału po pół kilo cukru. Ob. Minta był nieobecny. Przygotowano

\footnotetext{
83 Tamże.

${ }^{84}$ W tym wydziale było to około $41 \%$. W tej grupie za „nieusprawiedliwioną nieobecność" - 26,76\%. Dane statystyczne wyprowadzone...

85 „Żegluga Gdańska”.

86 AO-MZKGG, 1946/1065.

87 Tamże.
} 
odpowiednią listę i gdy obywatel Minta przybył przedłożyłem mu pismo i listę. Przeglądnął i zapytał, dlaczego nie ma Andreysa i Schmidta. Powiedział, że to dobrzy pracownicy i kazał ich dopisać ${ }^{88}$.

Oburzyło to pracownika, który wykonał polecenie dyrektora, ale nazwiska te podkreślił i napisał obok „Niemcy”. Taką listę zaniósł dyrektorowi do podpisu, ten zaś

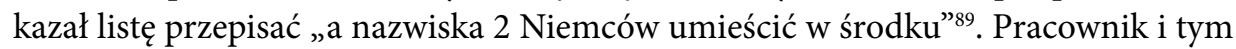
razem wykonał polecenie. Nowa lista została przez dyrektora podpisana. Ruszyła dalej do dyrekcji głównej MZK GG, która stwierdziła, że Niemcy „cukru dostać nie powinni"90. Alfred S. triumfował, odpowiedź dyrekcji z satysfakcją zaniósł do swojego zwierzchnika, na co ten odparł: „Co mi pan pokazujesz, zrób pan jak chcą" ${ }^{1}$. Nazwiska Niemców zostały więc przekreślone. Kiedy niebawem pojawił się cukier, jego rozdziałem według ostatniej listy zajął się woźny Gronkowski. Akcja trwała już dwa dni, gdy raportujący biuralista postanowił ją skontrolować, zapytał więc woźnego „czy wszyscy już pobrali?" "22, a gdy usłyszał odpowiedź odmowną, przejrzał listę, na której pobierający kwitowali odbiór swojego przydziału. Wtedy zauważył, że przy skreślonych nazwiskach Niemców figurują podpisy dwóch Polaków. Poproszony o wyjaśnienia woźny odparł, że dyrektor Minta „kazał usypać z przygotowanych torebek i zrobić dwie porcje dla Andresa ${ }^{93}$ i Schmidta" ${ }^{94}$. Przydziały Niemców odebrali ich zamustrowani na tych samych statkach koledzy. Tym sposobem Minta ominął zakazy i niedocenionym pracownikom zapewnił przydział.

Zdaniem Alfreda S. dyrektor otaczał ich wyjątkową opieką: „Wielokrotnie spotkałem się z pytaniami. Czy Andres i Schmidt otrzymali konserwy? Czy przyniósł Pan (na wypłatę) pieniądze dla Andresa i Schmidta? Czy Andres i Schmidt otrzymują kartki żywnościowe I kategorii itp.?"95. W swoich zarzutach zwolniony pracownik szedł jeszcze dalej, sugerował, że dyrektor specjalnie unika zatrudnienia odpowiednio wykwalifikowanych polskich pracowników, chroniąc miejsca pracy Niemców. Było to poważne posądzenie, wymagało również uzasadnienia. Informator twierdził, że kiedy w czerwcu 1946 roku doszło do wysiedlenia Niemców, „Ob. Minta poczynił starania o ich reklamacje (chodzi o Andreysa i Schmidta) wraz z żonami i dziećmi”. Reklamacje dla obu uzyskano i kiedy były już do odbioru w biurze, Schmidt poprosił o wstawiennictwo dla jeszcze czterech osób: „Ob. Minta, gdy przyszedł powiedział, że to trzeba zrobić”. Byli to członkowie rodziny Schmidta: wychowankowie, teściowa i teść. Oburzyło to pracownika, który w proteście odrzekł, że jest już za późno

\footnotetext{
88 Tamże.

89 Tamże.

90 Tamże.

91 Tamże.

92 Tamże.

93 Tak zapewne raportujący zapisał nazwisko Herberta Andreysa.

94 Tamże.

95 AO-MZKGG, 1946/1065.
} 
na korektę dokumentu, a poza tym „ci niemcy nie są nikomu potrzebni”" ${ }^{\text {. }}$. Minta pochylił się wówczas nad gotową reklamacją i wskazując wolne miejsce, zasugerował, aby tam właśnie dopisać dodatkowe osoby. Wywołało to zdecydowaną dezaprobatę mającego dopuścić się takiego fałszerstwa biuralisty, na co dyrektor odparł: „Tak, tu rzeczywiście cztery osoby się nie zmieszczą". Decyzji swej jednak nie zmienił, uznając, że „można ich dopisać na końcu”"97. Pracownik zastrzegł, że nawet gdy polecenie wykona, wykaz dodatkowych osób znajdzie się poniżej pieczątki i podpisu jego

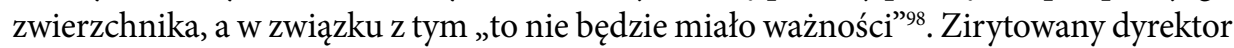
zabrał deklarację, informując, że sam zajmie się załatwieniem tej sprawy. Następnego dnia w biurze pojawiła się kartka od radcy prawnego MZK GG ${ }^{99}$, Alfred S. zapoznał się z jej treścią, zaznaczając w swoim raporcie, że dotarła do biura już „otwarta”. Jej treść przekazał kolegom z pokoju. Miał się czym chwalić, ku jego zadowoleniu radca stwierdził, że „przepisy nie pozwalają na reklamacje takich członków rodzin”100. Gdy opinia dotarła do zwierzchnika, ten nakazał ją zniszczyć. Tego samego dnia w gabinecie Minty pojawił się Schmidt, pytając „o rezultat jego staran’”101. Dyrektor, choć mówił półgłosem, był doskonale słyszany przez swojego pracownika, który w raporcie streścił sekretną rozmowę. Minta tłumaczył Schmidtowi, że dowiedział się o wszystkim zbyt późno, aby skutecznie interweniować, ale obiecał urlop, podczas którego rodzina będzie mogła się spotkać i ułożyć swoje sprawy. Na koniec starał się pocieszyć Niemca, mówiąc: „So kann nicht immer werden”"102. Donosiciel uznał, że powinien koniecznie przekazać te słowa dalej: „Nie wiem co one miały oznaczać”. Wyraźnie sugerował zmowę obu mężczyzn. Po wyjściu dyrektora i Schmidta zapytał współpracowników, czy byliby gotowi potwierdzić jego wersję rozmowy. Żaden z nich jednak nie zamierzał tego uczynić, doradzali mu, „aby nie psuł wzajemnych stosunków” ${ }^{103}$. Na próżno, ten nadal starannie i z odpowiednim nastawieniem obserwował swojego szefa.

\section{Sucharki na święta}

Zwolniony pracownik był również zdania, że dyrektor w rażący sposób podniósł stawki zatrudnionym u siebie Niemcom i że uczynił to z konkretnego powodu: „Pomiędzy 20 maja a 10 czerwca ob. Minta dowiedział się, że w stoczniach niemcy są lepiej płatni jak w Żegludze. Gdy przyszedł, natychmiast kazał wystosować pismo o podwyżkę

96 Tamże

97 Tamże.

98 Tamże.

99 Opinię tę wydał prawdopodobnie zatrudniony na tym stanowisku i w tym czasie (do lipca 1948 r.) radca Jerzy Wolicki-Wolszleger, AO-MZKGG, 1946/864

100 AO-MZKGG, 1946/1065.

101 Tamże.

102 „Zawsze tak nie może być”.

103 AO-MZKGG, 1946/1065. 
dla Niemców z 8 zł na 12 zł za godzinę i wysłał mnie z tym pismem abym zaraz załatwił. Prośba jego została uwzględniona"104. Alfred S. uważał, że przyznane Niemcom wynagrodzenie było zbyt wysokie wobec tego, które proponowano przyjmowanym Polakom. O tym, że dyrektor działał na korzyść Niemców, świadczyć miało nierówne traktowanie obu nacji. Dotyczyło ono dotrzymywania terminu sporządzenia listy przepracowanych godzin, które kierownicy statków przygotowywali co 10 dni dla Wydziału Finansowego. Kiedy pewnego razu w wyniku braku dostarczenia raportów dwóm pracownikom „przepadło" po kilka dni, dyrektor skomentował to w sposób następujący: „Raz muszą się porządku nauczyć”. Inaczej jednak miał zareagować, gdy „opuszczony został jeden dzień pracy ob. Schrödera, zrehabilitowanego niemca (ostatni wyraz zamazano)" 105 . Kiedy autor naszego raportu zameldował o tym swojemu szefowi, ten zrobił mu „bardzo ostrą wymówkę". Ta troska o Niemców była solą w oku Alfreda S., zdemobilizowanego w marcu 1946 roku żołnierza wojska polskiego, który w swoim życiorysie nadmieniał, że w niemieckiej niewoli spędził lata 1939-1945. Stał się kolekcjonerem wszelkich „narodowych” wykroczeń swego dyrektora, który ośmielał się - i to po kilkakroć - upominać woźnego Gronkowskiego, „aby Niemkom pracującym w podwórzu krzywdy nie czynić, choć żadnej krzywdy im nie wyrządzał"106.

Do kolejnej konfliktowej sytuacji doszło przed Wielkanocą w 1946 roku podczas rozdziału wśród pracowników „Żeglugi Gdańskiej” paczek z UNRRA ${ }^{107}$. Autor raportu zanotował: „W czasie wydawania ob. Kokotowi Antoniemu nadszedł ob. Minta $z$ ob. Puchaczem ${ }^{108}$. Ob. Minta zaczął grzebać w paczce swojego pracownika i wyciągnąwszy duże opakowanie sucharków zaczął mówić "Co pan z tem będziesz robił, panu to niepotrzebne " 109 . Podobnie zareagował, gdy znalazł czekoladę: „Pan przecież czekolady nie lubi, co Pan będziesz z tym robił”. Zastępca dyrektora Stefan Puchacz miał to skomentować: „Panie dyrektorze, przecież on ma żonę i drobne dzieci" ${ }^{110}$. Minta odłożył czekoladę i przestał przeszukiwać paczkę, ale nie zrezygnował z pozyskania sucharków. Postanowił uczynić to sposobem. Raportujący tak opisał całą sytuację: „Widząc, że ja płacę za paczkę papierosów (ob. Kokot kilkakrotnie mi papierosy amerykańskie kupował po 3 zł sztuka), też zapłacił za paczkę, którą otrzymał, dając $100 \mathrm{zł}$. Kokot nie miał reszty i chciał oddać $100 \mathrm{zł}$ z tego powodu. Ob. Minta już wyciągnął rękę, ale ją cofnął i powiedział »Weź pan te $40 \mathrm{zl}$, to będzie

104 Tamże.

105 Tamże.

106 Tamże.

107 UNRRA (United Nations Relief and Rehabilitation Administration, Organizacja Narodów Zjednoczonych do spraw Pomocy i Odbudowy), organizacja utworzona w 1943 r. w celu udzielenia pomocy zniszczonym podczas drugiej wojny krajom.

108 Kapitan Stefan Puchacz, zastępca dyrektora inż. Janusza Minty. M. Gwiazda, Komunikacja miejska wybrzeża Gdańskiego..., s. 12; APG, 1164/1333, s. 201-205, Dokumenty Urzędu Wojewódzkiego w Gdańsku. Kwalifikacje pracowników MZK GG 1945-1947.

109 AO-MZKGG, 1946/1065.

110 Nieco dalej napisał: „Ob. Kokot jest żonaty i ma 2 dzieci, 3 letnią i 1 roczne”. 
za sucharki «". Alfred S. zaznaczył, że jego zdaniem taka paczka kosztowała znacznie więcej, bo 200-250 zł. Okazało się, że sucharki stanowiły prezent świąteczny dla Niemek, które pracowały na podwórzu za budynkiem przy ulicy Grodzkiej 17, uprzątając gruz. Dyrektor miał przy tym powiedzieć, że „musi im coś dać, bo są biedne” ${ }^{111}$. Zdaniem pracownika kobiety nie zasługiwały na takie frykasy, były bowiem „pracownicami kiepskimi i gdy się ich nie doglądało lubiły stać bezczynnie" ${ }^{\prime 12}$.

W przedsiębiorstwie MZK GG pracowali głównie mężczyźni, kobiety z wykształceniem mogły liczyć na etat w biurze, większość jednak trafiała do Wydziału Ruchu jako konduktorki. Najniższe płace otrzymywały robotnice zatrudniane przy pracach porządkowych, jak określano sprzątanie. Wśród nich istotną grupę stanowily osoby z byłego Wolnego Miasta Gdańska, starsze i młode kobiety, w tym wdowy. W ich życiorysach pojawiają się zdania: „została mi wydzielona trzecia grupa” lub „mąż został wzięty do wojska niemieckiego i do dnia dzisiejszego nie powrócił”113. Jak wcześniej wspomniano, kobiety musiały przedstawić dokumenty potwierdzające polską narodowość i przejść w określonym czasie procedurę rehabilitacyjną. Nie wszystkie temu podołały. Kartę jednej z kandydatek do pracy, Elżbiety Kaufmann ${ }^{114}$, opatrzono informacją: „nie mogła na razie podać narodowości. Po przedłożeniu dokumentów będzie ewentualnie przyjęta”. Marta Bankiewicz ${ }^{115}$, urodzona w 1891 roku wdowa i matka trójki dzieci, w swoim podaniu „o otrzymanie pracy” podkreśliła swoją „przynależność państwową, gdańską" i nie ukrywała, że w 1942 roku została „zapisana do III grupy”"116. Przeszła pozytywnie rehabilitację i jako „robotnica" zatrudniona została najpierw w stołówce, potem przy sprzątaniu Warsztatów Głównych. Dostawała jedną z najniższych możliwych stawek, tj. 4,20 zł na godzinę.

Na początku 1946 roku trafiło do MZK GG kilka młodych kobiet, podczas wojny zatrudnionych w Gdańsku „przy tramwajach” oraz w Gdyni „przy Trolleybusach w die städtischen Verkehrsbetriebe". W tej grupie znalazły się Wanda Komar ${ }^{117}$ i Kunegunda Jach ${ }^{118}$, która w swoim podaniu napisała: „Jestem Polką i znam dobrze wyszkolenia konduktorskie [...]. Pracowałam w Miejskich Zakładach Komunikacyjnych jako konduktorka, aż do wkroczenia wojsk Rosyjskich" ${ }^{119}$. Nie wiemy, jak długo była zatrudniona w MZK GG, nie podano daty rozwiązania umowy, za to jej kartę osobową przekreślono czerwonym ołówkiem, całość zaś opatrzono dużym napisem - „niemka”. Wypada uznać, że w jej przypadku stanowiło to wystarczający

111 AO-MZKGG, 1946/1065.

112 Tamże.

113 AO-MZKGG, 1946/614. W tym konkretnym przypadku był to marzec $1945 \mathrm{r}$.

114 Tamże.

115 Bankowitz, AO-MZKGG, 1946/36.

116 Chodzi oczywiście o volkslistę i - dotyczące wpisywania się nań - rozporządzenie namiestnika Okręgu Rzeszy Gdańsk-Prusy Zachodnie Alberta Forstera z 22 lutego 1942 r.

117 Od grudnia 1943 do marca 1945 r., AO-MZKGG, 1946/413.

118 AO-MZKGG, 1946/365.

119 W innym miejscu podała, że cztery lata. 
powód do zwolnienia. Weryfikacji, jak można przypuszczać, nie przeszła również biuralistka, panna Anna Mauzer ${ }^{120}$. W jej sprawie w styczniu 1946 roku dyrekcja MZK GG zwróciła się do zarządu miasta Bydgoszczy, skąd pochodziła dziewczyna: „Prosimy o możliwe spieszne przeprowadzenie sprawy i uproszczenie ew. formalności, gdyż w/w na naszym terenie okazała się niezbędną pracowniczką i pragnęliśmy możliwie szybko korzystać z dalszej jej pracy, co uwarunkowane jest jednak przeprowadzeniem dowodu rehabilitacyjnego"121. Opinia musiała być negatywna, skoro jej kartę opatrzono adnotacją: „decyzją dyrekcji i Rady Zakładowej zwolniona 1.02.1946 r. jako niemka". Nic nie wiemy o jej dalszych losach. Być może podjęła decyzję o wyjeździe, jak Agnieszka i Dorota z rodziny Drewsów ${ }^{122}$, matka i córka, po rehabilitacji zatrudnione jako „sprzątaczki - fizyczne”. W grudniu 1946 roku wyjechały do Niemiec - taka informacja wpisana została do ich akt.

\section{Archeologia codzienności}

Wkrótce po zajęciu Gdańska, w kwietniu 1945 roku, w przedwojennym budynku dyrekcji Danziger Elektrische Straßenbahn przy Jäschkentaler Weg ${ }^{123} 48$, w którym zainstalowały się MZK, znaleziono spory zapas niemieckich biletów, które po przestemplowaniu wykorzystywano jeszcze przez wiele miesięcy ${ }^{124}$. Tabor, ściągany z torowisk, wyłuskiwany z barykad, transportowany do warsztatów, wracał na ulice i miał je przemierzać jeszcze przez długie lata. Polskie tramwaje, słynne Konstale N-ki, konstrukcją nawiązujące do niemieckiej wojennej produkcji Kriegsstraßenbahnwagen, pojawiły się na ulicach miast, $w$ tym także Gdańska, dopiero na początku lat pięćdziesiątych. Proces wymiany trwał więc długo. Z ludźmi poszło szybciej, niemieccy mieszkańcy Wolnego Miasta Gdańska opuszczali je sukcesywnie, w ciągu kilku powojennych miesięcy zmienił się całkowicie jego skład ludnościowy. Ci, którzy doń przybyli, w sporej części pochodzili z terenów przyległych: ziem dawnego zaboru pruskiego, województwa pomorskiego ${ }^{125}$, obszaru wcielonego do Rzeszy. Bycie miejscowym, jak to określano - autochtonem, było w latach powojennych źle odbierane. Należało przejść proces weryfikacyjny, w razie konieczności poddać się rehabilitacji, przyprowadzić poświadczających polskie pochodzenie świadków, a w życiorysie i podaniu umieścić koniecznie stwierdzenie: „Jestem Polakiem”.

120 AO-MZKGG, 1946/1037.

121 Tamże.

122 AO-MZKGG, 1946/164-165.

${ }^{123}$ Jaśkowa Dolina. Nazwa niemiecka ulicy figurowała na oficjalnych dokumentach firmy tzw. formatkach - jeszcze w kwietniu $1946 \mathrm{r}$.

${ }^{124}$ Miał je odszukać Stanisław Borkowski. Relacja na ten temat zob. A. Preys, Tramwajarskie wspomnienia, „Głos Wybrzeża” 25.03.1963 r.

125 Powstało 12 sierpnia 1919 r. Jego stolicą był Toruń. 
W lutym 1946 roku zatrudniono w MZK GG na stanowisku kierowniczki kontroli Lucynę Rzewuską ${ }^{126}$. Wkrótce została urzędniczką do „spraw zleconych”, a wreszcie pełniącą obowiązki zastępcy Naczelnika Wydziału Aprowizacji. 29 grudnia 1946 roku, prosząc o miesięczny urlop, tłumaczyła, że nie mogła go wykorzystać wcześniej $\mathrm{z}$ powodu nawału prac, wynikających z konieczności uporządkowania akt poniemieckich, to zadanie zlecił jej dyrektor K. Jędrusik. O jakie akta chodziło? Ile z nich zdecydowano się wyrzucić na śmietnik historii? W zawierusze dziejów najmniej trwałym elementem jest człowiek. Zapisane na kilku kartkach czyjeś losy, jedno zdjęcie, podanie, życiorys, zużyty bilet są w stanie spłonąć w ciągu paru sekund. Tamta codzienność, nasza codzienność, rzadko wydaje się nam godna przechowania. Pozostają po niej okruchy, rzeczy niekiedy przez szczęśliwy tylko przypadek zachowane.

Bibliografia:

Archiwum Państwowe w Gdańsku.

Archiwum Przedsiębiorstwa Gdańskie Autobusy i Tramwaje sp. z o. o., akta osobowe pracowników Miejskich Zakładów Komunikacyjnych i Międzykomunalnych Zakładów Komunikacyjnych Gdańsk Gdynia.

Baziur G., Armia Czerwona na Pomorzu Gdańskim 1945-1947, Warszawa 2003.

Bykowska S., Rehabilitacja i weryfikacja narodowościowa ludności polskiej w województwie gdańskim po II wojnie światowej, Gdańsk 2012.

„Dziennik Bałtycki”, wybrane artykuły z lat 1945-1951.

„Głos Wybrzeża” z $1961 \mathrm{r}$.

Gąsiorowski A., Szare Szeregi na Pomorzu 1939-1945, Toruń 1998.

Glinecki T., Atak na Gdańsk od strony Żuław w świetle dziennika działań bojowych 2. Armii Uderzeniowej za marzec 1945 roku [w:] Żuławy w 1945 roku. Niedomknięte księgi, red. T. Glinecki M. Owsiński, Sztutowo 2018.

Gwiazda M., Komunikacja miejska wybrzeża Gdańskiego. Odbudowa i rozwój w latach 1945-1980, Gdańsk 1992.

Kieser R., Zatoka Gdańska 1945. Dokumentacja dramatu, Gdańsk 2002.

Komunikacja miejska w aglomeracji gdańskiej. Rys historyczny. Stan obecny. Prognoza rozwoju, Gdańsk 1976.

Przegląd statystyczny miasta Gdańska 1945-1950, z uzupełnieniami za rok 1951.

Podoski K., Województwo gdańskie w latach 1945-1959, Gdańsk 1958.

Półwysep Helski. Historia orężem pisana, red. A. Drzewiecki, M. Kardas, Toruń 2009.

Rocznik statystyczny miasta Gdańska 1946-1965, Gdańsk 1965.

Stryczyński M., Gdańsk w latach 1945-1948. Odbudowa organizmu miejskiego, Wrocław 1981. Urząd Statystyczny w Gdańsku, Prezydium Wojewódzkiej Rady Narodowej. Wydział Statystyki w Gdańsku, Rocznik statystyczny 1946.

126 AO-MZKGG, 1946/995. 
Walicka M., Próba wspomnień. Gdańsk 1945-1946, Gdańsk 1968.

Zomkowski S., Tramwajem przez Gdańsk, Gdańsk 2015.

\section{Streszczenie}

Zarząd Miejski powołał w kwietniu 1945 roku Miejskie Zakłady Komunikacyjne miasta Gdańska, które przekształcono dość szybko, bo już po roku, w duże, łączące trzy nadmorskie miasta przedsiębiorstwo Międzykomunalne Zakłady Komunikacyjne Gdańsk Gdynia. Nowa polska administracja czuwała nad zinwentaryzowaniem i zabezpieczeniem istniejącej infrastruktury, wszelkich dóbr, które uznawano za użyteczne. Jej zadaniem było również stworzenie warunków do życia dla mieszkających tu ludzi, pozyskanie bazy mieszkaniowej i miejsc pracy dla tych, którzy mieli tu niebawem przybyć. Dawni niemieccy gdańszczanie powoli, lecz sukcesywnie opuszczali swoje miasto, z danych z 31 lipca 1945 roku wynika, że w mieście przebywało 122,8 tys. mieszkańców, z czego 107,2 tys. stanowili Niemcy. Polacy zdominowali ich dopiero na przełomie października i listopada 1945 roku. Niezwykle istotnym etapem przywracania normalności w funkcjonowaniu trzech nadmorskich miast była odbudowa połączeń komunikacyjnych. Ich uruchomienie w możliwie najkrótszym czasie i w kluczowych kierunkach stanowiło prawdziwe wyzwanie. Starannie prowadzona ewidencja pracownicza Miejskich Zakładów Komunikacyjnych, a następnie Międzykomunalnych Zakładów Komunikacyjnych Gdańsk Gdynia to zespół kilku tysięcy teczek, zawierających liczne dokumenty i ilustrujących przebieg pracy osób zatrudnionych w tym przedsiębiorstwie. Niemcy stanowili istotną grupę wśród pracowników przedsiębiorstwa. Pracownicy firmy Verkehrsbetriebe Danzig Gothenhafen AG jako specjaliści byli niezwykle cenni, wnieśli istotny wkład w przywrócenie działania komunikacji w mieście. Można odnieść wrażenie, że ich obecność była szczególnie istotna w kluczowych wydziałach przedsiębiorstwa, określanych niekiedy mianem eksploatacyjnych, jak tramwajowy, autobusowy, trolejbusowy i „Żegluga Gdańska”.

Artykuł stanowi próbę opisania tej grupy na podstawie informacji i przekazów zawartych $\mathrm{w}$ aktach osobowych i wewnętrznej korespondencji, ustalenia pewnych prawidłowości, ukazania, jak w pierwszych powojennych latach przebiegał proces wymiany ludności w istotnym dla funkcjonowania nadmorskiego regionu dużym przedsiębiorstwie komunikacyjnym. Przykłady $\mathrm{w}$ nim zawarte stanowią zapis konkretnych wydarzeń, wyniesionych z niepamięci, istotnych, bo spisanych w czasie, gdy miały one miejsce.

Słowa kluczowe: Miejskie Zakłady Komunikacyjne w Gdańsku, Międzykomunalne Zakłady Komunikacyjne Gdańsk Gdynia, gdańszczanie, Niemcy w Gdańsku, komunikacja w Gdańsku, pracownicy, konflikty narodowościowe

\section{Abstract}

The Municipal Board established in April 1945 Miejskie Zakłady Komunikacyjne (Municipality Transport Company) of the city Gdańsk, which was soon, after a year, transformed into the large company - Międzykomunalne Zakłady Komunikacyjne Gdańsk Gdynia (Gdańsk Gdynia Inter-municipality Transport Company) joining three coastal cities. The new Polish administration took care of inventorying and securing the existing infrastructure and all goods considered to be useful. It also aimed at creating proper living conditions for residents already living here, creating housing resources and working places for those who were to come. Former German Gdańsk residents were leaving their city slowly but successively; based on data of $31^{\text {st }}$ July 1945 
there were 122800 citizens of whom 107200 were Germans. Poles did not dominate them until the turn of October and November 1945. The truly crucial phase of bringing back the normality to functioning of three coastal cities was the reconstruction of transportation connections. Their initiation in the shortest possible time and within the key directions was the real challenge. Carefully managed employees' documentation of Miejskie Zakłady Komunikacyjne and next Międzykomunalne Zakłady Komunikacyjne is the collection of a few thousand files consisting of numerous documents, illustrating the course of employment of persons employed in the company. Germans were the significant group of the company employees. Until recently the employees of Verkehrsbetriebe Danzig Gothenhafen AG (VDG), they were extremely valuable specialists and contributed significantly to the restoration of the operation of transportation in the city. One could have the impression that the presence of Germans was crucial especially in the key divisions of the company, sometimes referred to as operation ones, such as tram, bus trolleybus divisions and "Żegluga Gdańska” (Gdańsk Waterway Transport).

The article is an attempt to describe the above mentioned group based on the information from the personal files, the internal correspondence and reports; to define certain regularities, to show how in the first years after the war went the process of the population exchange in the crucial for the functioning of the coastal region large transportation company. The examples given in the article are the record of the particular events, brought back from oblivion, important because written at the time they happened.

Keywords: Miejskie Zakłady Komunikacyjne w Gdańsku (Municipality Transport Company), Międzykomunalne Zakłady Komunikacyjne Gdańsk Gdynia (Gdańsk Gdynia Inter-municipality Transport Company), Gdańsk citizens, Germans in Gdańsk, Transportation in Gdańsk, Employees, nationality-based conflicts 